\title{
Effect of Different Doses of Sulphur and Zinc with NPK on Different Growth Parameters and Yield Attribute of Yellow Mustard (Brassica compestris L.) cv. Sunanda
}

\author{
Dogendra Kumar Sahu*, Narendra Swaroop, Dileshwar Prasad, \\ Dineshwar Singh Kanwar and Prahlad Singh
}

\begin{abstract}
Department of Soil Science and agricultural chemistry, Sam Higginbottom University of Agriculture, Technology and Sciences, Allahabad, Uttar Pradesh, India
\end{abstract}

*Corresponding author

\begin{abstract}
Keywords
Sulphur, Zinc, Different Growth Parameter, Yellow Mustard

Article Info

Accepted:

10 February 2018

Available Online:

10 March 2018 factorial randomized block design with three replications, consisting of nine treatments. It was observed that the best yield attributes characters in treatment $T_{7}$ (@30 kg Sulphur ha ${ }^{-1}$ $\left.+1.35 \mathrm{~kg} \mathrm{Zinc} \mathrm{ha}{ }^{-1}\right)$ in respect to different day's intervals i.e. 25, 50, 75, 100 and 125 days after sowing (DAS). Plant height was 30.53, 85.56, 113.53, 135.53, and $154.46 \mathrm{~cm}$ found to be significant at 50,75, 100 and 125 DAS but non-significant at 25 DAS, No. of leaves plant $^{-1}$ were $4.46,11.4,61.93,74.2$ and 49.33 found to be non-significant at $25,75,100$ DAS but significant at 50 and 125 DAS. No. of Branches plant ${ }^{-1}$ were 3, 15.2, 26.73 and 32.33 found to be non-significant at 50, 75 DAS but significant at 100 and 125 DAS. No. of siliqua plant ${ }^{-1}$ was 143.2 found to be significant, $\mathrm{T}_{8}$ (@30 kg Sulphur ha ${ }^{-1}+2.75 \mathrm{~kg}$ Zinc ha ${ }^{-1}$ ) found highest Seed yield $\left(\mathrm{q} \mathrm{ha}^{-1}\right)$ and Test weight $(\mathrm{g})$ which were 11.13 and 3.81 respectively found to be significant. Highest Stover yield $\left(\mathrm{q} \mathrm{ha}^{-1}\right)$ found in $\mathrm{T}_{8}$ (@30 kg Sulphur ha ${ }^{-1}+2.75 \mathrm{~kg} \mathrm{Zinc} \mathrm{ha}^{-1}$ ) which was 15.70 found to be non- significant. Highest B: $\mathrm{C}$ (1.57) was recorded in $\mathrm{T}_{8}$ (@ $30 \mathrm{~kg}$ Sulphur ha ${ }^{-1}+2.75 \mathrm{~kg}$ Zinc ha ${ }^{-1}$ ). However, since these findings are based on one year experiment and therefore, further research may be conducted to substantiate it under Allahabad agro climatic conditions.
\end{abstract}

\section{A B S T R A C T}

The experiment was carried out at Soil Science and agricultural chemistry research farm SHUATS, Allahabad during rabi season 2016-17. The experiment was laid out in $3 \times 3$

\section{Introduction}

Mustard is the second most important edible oil-seed crop after groundnut. It plays an important role in the oil-seed economy of the country. India occupies the third position in mustard production in World after China and Canada. In India, during 2009-2010, the mustard crop had production of about $6.40 \mathrm{mt}$. from an area of $6.45 \mathrm{~m}$ ha with an average productivity of $1184 \mathrm{~kg} \mathrm{ha}^{-1}$. However, in U.P it is grown in $0.82 \mathrm{~m}$ ha with production of $0.90 \mathrm{mt}$. The average productivity in U.P is $1141 \mathrm{~kg} \mathrm{ha}^{-1}$, which is $3.6 \%$ lower than the national average productivity Indian mustard markedly responded to sulphur fertilization in 
oilseeds, sulphur plays a vital role in quality and development of seed. The importance of sulphur fertilization for increasing yield and quality of Indian mustard is being increasingly recognized. However, the information regarding optimum level of sulphur and its influences on seed yield and quality of different varieties of mustard is meagre. Probably for these reasons mustard crop needs comparatively higher amount of sulphur for proper growth and development and higher yields. Sulphur is considered to occupy fourth place among major plant nutrient after nitrogen, phosphorus and potassium. It increases phosphorus uptake by plant and nitrogen in protein synthesis and is indispensable for the synthesis of essential amino acid like cysteine and methionine. Besides, sulphur is also involved in various metabolic processes of plants. It is a constituent of glutathione, a compound supposed to be associated with the plant respiration and the synthesis of essential oils. Sulphur also plays a vital role in chlorophyll formation (Yadav et al., 2016).

The term "mustard" is used to describe several plants in the Brassica and Sinapis genera which are used as sources of food. There are a number of different types of mustard which are cultivated for different products, including greens and leaves. The incredible diversity and flexibility of mustard plants can cause them to pop up in a wide variety of places, from traditional American Southern cuisine to fiery Indian curries. B. nigra produces black seeds with a very strong and distinctive flavour. Black mustard is often used in Indian and Southeast Asian cooking, where it is incredibly popular; you may have encountered whole mustard seeds in marinades and curries if you eat a lot of Southeast Asian food. Black mustard can also be ground into condiment form. As a condiment, mustard is incredibly diverse. Mustard can be ground into a smooth puree or mixed with whole seeds for more texture. It can also be blended with things like horseradish for spicy mustard, which can be quite fiery, or sugar, for sweet mustard. Some cultures have a tradition of making mustard with beer or wine, creating a very distinctive, complex flavour which complements a range of foods (Piri, 2012).

India is amongst the largest vegetable oil economic in the world. Mustard is rich in minerals like calcium, manganese, copper, iron, selenium, zinc, vitamin $\mathrm{A}, \mathrm{B}, \mathrm{C}$ and proteins. $100 \mathrm{~g}$ mustard seed contains $508 \mathrm{kcal}$ energy, 28.09 g carbohydrates, 26.08 g proteins, $36.24 \mathrm{~g}$ total fat and $12.2 \mathrm{~g}$ dietary fiber. The physical properties of soil play an important role in determining its suitability for crop production. The characteristics like support in power and bearing capacity, tillage practices, moisture storage capacity, drainage, ease of penetration by roots, aeration, retention of plant nutrient and its availability to plant. It includes bulk density, particle density, porosity, soil texture and soil colour too. Sulphur plays a significant role in increasing production especially in oilseeds (Upadhyay et al., 2016).

The nutrient elements of major significance for yield and quality of yellow mustard are nitrogen, phosphorus and sulphur. Nitrogen is an important constituent of protein for which the plants take inorganic nitrogen in the form of ammonium or nitrate. Higher the nitrogen greater would be the protein and protoplasm which would increase, in turn greater cell size, leaf area index resulting into greater photosynthetic activity. Thus, the nitrogen help in formation in of a larger frame on which more flowers and eventually more pods can develop. This shows a positive link between larger nitrogen supply and higher seed yield. In case of nitrogen deficiency the leaves and stems become light green in colour. In case of acute shortage the leaves may become chlorotic associated with purple 
coloration and older leaves may wither. The plants have poor growth with thin and short stems having few or practically no branches (Bharose et al., 2010).

\section{Materials and Methods}

The experiment was conducted in the research farm of Department of Soil Science, Department of Soil Science and Agricultural Chemistry, Sam Higginbottom University of Agriculture, Technology and Sciences Allahabad which situated six $\mathrm{km}$ away from Allahabad city on the right bank of Yamuna river. The experimental site is located in the sub - tropical region with $25^{\circ} 22^{\prime} 45.14^{\prime \prime} \mathrm{N}$ latitude $81^{\circ} 54^{\prime} 49.95^{\prime \prime} \mathrm{E}$ longitudes and 98 meter the sea level altitudes. The experiment was laid out in a $3^{2}$ RBD factorial design with three levels of each Sulphur and Zinc with nine treatments, each consisting of three replicates.

The total number of plots was 27. Yellow Mustard (Brassica compestris L.) "CV. Sunanda" were sown in rabi season plots of size $2 \times 2 \mathrm{~m}$ with row spacing $30 \mathrm{~cm}$ and plant to plant distance $10 \mathrm{~cm}$. The Soil of experimental area falls in order of Inception and is alluvial in nature; both the mechanical and chemical analysis of soil was done before starting of the experiment to ascertain the initial fertility status (Table 1 and 2). The soil samples were randomly collected from 0$15 \mathrm{~cm}$ depths prior to tillage operations. The treatment consisted of nine combination of inorganic source of fertilizers $\mathrm{T}_{0}\left(@ 0 \mathrm{~S} \mathrm{~kg} \mathrm{ha}{ }^{-}\right.$

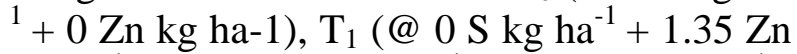
kg ha ${ }^{-1}$ ), $\mathrm{T}_{2}$ (@0 S kg ha ${ }^{-1}+2.75 \mathrm{Zn} \mathrm{kg} \mathrm{ha}^{-1}$ ), $\mathrm{T}_{3}$ (@15 S kg ha ${ }^{-1}+0 \mathrm{Zn} \mathrm{kg} \mathrm{ha}^{-1}$ ), $\mathrm{T}_{4}$ (@15 S $\left.\mathrm{kg} \mathrm{ha}^{-1}+1.35 \mathrm{Zn} \mathrm{kg} \mathrm{ha}{ }^{-1}\right), \mathrm{T}_{5}$ (@30 S kg ha ${ }^{-1}$ + 2.75 Zn kg ha ${ }^{-1}$ ), $\mathrm{T}_{6}$ (@30 S kg ha ${ }^{-1}+0 \mathrm{Zn}$ $\mathrm{kg} \mathrm{ha}^{-1}$ ), $\mathrm{T}_{7}$ (@30 Skg ha-1 $+1.35 \mathrm{Zn} \mathrm{kg} \mathrm{ha}^{-1}$ ), $\mathrm{T}_{8}$ (@30 S kg ha ${ }^{-1}+2.75 \mathrm{Zn} \mathrm{kg} \mathrm{ha}^{-1}$ ). The source of sulphur and zinc as milvet sulphur and zinc sulphate respectively.

\section{Results and Discussion}

\section{Different growth parameters}

Effect of different doses of Sulphur and Znic with NPK the important growth parameters of Yellow Mustard crop

\section{Plant height}

Plant height $(\mathrm{cm})$ plant $^{-1}$ was significantly increased according to table 3 by the application of different treatment of $\mathrm{S}$ and $\mathrm{Zn}$ (sulphur and zinc) interaction. 125 DAS, the maximum plant height of $154.53 \mathrm{~cm}$ was recorded in $\mathrm{T}_{8}-\mathrm{S}_{2} \mathrm{Zn}_{2}$ (@30 kg ha ${ }^{-1}+2.75 \mathrm{~kg}$ $\mathrm{ha}^{-1}$ ), which was significantly higher than other treatment. The minimum plant height was $152.2 \mathrm{~cm}$. was recorded in $\mathrm{T}_{0^{-}}-\mathrm{S}_{0} \mathrm{Zn}_{0}$ (@0 kg $\left.\mathrm{ha}^{-1}+0 \mathrm{~kg} \mathrm{ha}^{-1}\right)$. Similar results have also been recorded by Dubey et al., (2013) (Fig. 1).

\section{Number of leaves plant $^{-1}$}

The number of leaves plant ${ }^{-1}$ was significantly increased according to table 3 by the application of different treatment of $\mathrm{S}$ and $\mathrm{Zn}$ (sulphur and zinc) interaction. At 125 DAS, the maximum number of leaves 49.4 was recorded in $\mathrm{T}_{8^{-}} \mathrm{S}_{2} \mathrm{Zn}_{2}$ (@ $30 \mathrm{~kg} \mathrm{ha}^{-1}+2.75 \mathrm{~kg}$ $\mathrm{ha}^{-1}$ ). The minimum number of leaves was 46.4 recorded at 125 DAS in $\mathrm{T}_{0^{-}} \mathrm{S}_{0} \mathrm{Zn}_{0}$ (@0 $\left.\mathrm{kg} \mathrm{ha}^{-1}+0 \mathrm{~kg} \mathrm{ha}^{-1}\right)$. Similar results have also been recorded by Dubey et al., (2013) (Fig. 2).

\section{Number of branches plant ${ }^{-1}$}

The number of branches plant ${ }^{-1}$ was significantly increased according to table 3 by the application of different treatment of $S$ and $\mathrm{Zn}$ (sulphur and zinc) interaction.

At 125 DAS, the maximum plant branches of $32.06 \mathrm{~cm}$ was recorded in $\mathrm{T}_{8^{-}} \mathrm{S}_{2} \mathrm{Zn}_{2}$ (@30 kg $\left.\mathrm{ha}^{-1}+2.75 \mathrm{~kg} \mathrm{ha}^{-1}\right)$, which was significantly higher than other treatment (Fig. 3). 
Table.1 Physical analysis of soil

\begin{tabular}{|c|}
\hline Sand (\%) \\
\hline Silt (\%) \\
\hline Clay (\%) \\
\hline Textural class \\
\hline Bulk density $\left(\mathrm{g} \mathrm{cm}^{-3}\right)$ \\
\hline Particle density $\left(\mathrm{g} \mathrm{cm}^{-3}\right)$ \\
\hline Pore Space $(\%)$ \\
\hline Solid space $(\%)$ \\
\hline
\end{tabular}

\begin{tabular}{|c|c|}
\hline Bouyoucous Hydrometer & 62.71 \\
\hline method (Bouyoucous, 1927) & 23.10 \\
\hline $\begin{array}{c}\text { Graduated measuring cylinder Muthuval } \\
\text { (1992) }\end{array}$ & 1.22 \\
\hline $\begin{array}{c}\text { Graduated measuring cylinder Muthuval } \\
\text { (1992) }\end{array}$ \\
\hline $\begin{array}{c}\text { Graduated measuring cylinder Muthuval } \\
\text { (1992) }\end{array}$ \\
\hline $\begin{array}{c}\text { Graduated measuring cylinder Muthuval } \\
\text { (1992) }\end{array}$ \\
\hline
\end{tabular}

Table.2 Chemical Analysis of Soil Particulars Method Employed Results

\begin{tabular}{|l|}
\hline $\mathrm{pH}(1: 2)$ \\
\hline $\mathrm{EC}\left(\mathrm{dSm} \mathrm{H}^{-1}\right)$ \\
\hline Organic Carbon (\%) \\
\hline Available Nitrogen $\left(\mathrm{kg} \mathrm{ha}^{-1}\right)$ \\
\hline Available Phosphorus $\left(\mathrm{kg} \mathrm{ha}^{-1}\right)$ \\
\hline Available Potassium $\left(\mathrm{kg} \mathrm{ha}^{-1}\right)$ \\
\hline Available Sulphur (ppm) \\
\hline Available Zinc (ppm) \\
\hline
\end{tabular}

\begin{tabular}{|l|c|}
\hline Digital pH meter (Jackson, 1958) & 7.18 \\
\hline $\begin{array}{l}\text { EC meter (Digital Conductivity Meter) (Wilcox, } \\
\text { 1950) }\end{array}$ & 0.53 \\
\hline $\begin{array}{l}\text { Rapid titration method (Walkley and Black's } \\
\text { method 1947) }\end{array}$ & 0.5 \\
\hline $\begin{array}{l}\text { Alkaline potassium permanganate method (Subbaih } \\
\text { and Asija (1956) }\end{array}$ & 251.63 \\
\hline $\begin{array}{l}\text { Colorimetric method (Olsen } \text { et al., 1954) } \\
\text { Flame photometric method (Toth and Prince, 1949) }\end{array}$ & 20.41 \\
\hline Turbidemetric (Bardsley and Lancaster 1960) & 130.64 \\
\hline Spectrophotometer (Shaw \& Dean 1952) & 9.82 \\
\hline
\end{tabular}

Table.3 Plant growth parameter

\begin{tabular}{|c|c|c|c|c|c|c|c|c|c|c|c|c|c|c|}
\hline \multirow{2}{*}{$\begin{array}{l}\text { Treatmen } \\
\mathrm{t}\end{array}$} & \multicolumn{5}{|c|}{ Plant height (cm) } & \multicolumn{5}{|c|}{ Number of leaves } & \multicolumn{4}{|c|}{ Number of branches } \\
\hline & $\begin{array}{c}25 \\
\text { DAS }\end{array}$ & $\begin{array}{c}50 \\
\text { DAS }\end{array}$ & $\begin{array}{c}75 \\
\text { DAS }\end{array}$ & $\begin{array}{c}100 \\
\text { DAS }\end{array}$ & $\begin{array}{c}125 \\
\text { DAS }\end{array}$ & $\begin{array}{c}25 \\
\text { DAS }\end{array}$ & $\begin{array}{c}50 \\
\text { DAS }\end{array}$ & $\begin{array}{c}75 \\
\text { DAS }\end{array}$ & $\begin{array}{c}100 \\
\text { DAS }\end{array}$ & $\begin{array}{c}125 \\
\text { DAS }\end{array}$ & $\begin{array}{c}50 \\
\text { DAS }\end{array}$ & $\begin{array}{c}75 \\
\text { DAS }\end{array}$ & $\begin{array}{c}100 \\
\text { DAS }\end{array}$ & $\begin{array}{c}125 \\
\text { DAS }\end{array}$ \\
\hline $\mathbf{T}_{0}$ & 29.53 & 70 & 80.8 & 76 & 152.2 & 3.93 & 10.6 & 11 & 73.4 & 45.4 & 2.53 & 12.8 & 25.06 & 31.6 \\
\hline $\mathbf{T}_{1}$ & 29.86 & 81.8 & 82.8 & 81.4 & 153.66 & 4.06 & 9.6 & 10.2 & 73.46 & 49 & 2.66 & 13.6 & 25.33 & 30 \\
\hline $\mathbf{T}_{2}$ & 29.86 & 83.4 & 84.6 & 82.2 & 153.06 & 4.26 & 11.6 & 10.8 & 73.66 & 46.8 & 2.26 & 14 & 25.33 & 32.6 \\
\hline $\mathbf{T}_{3}$ & 30.06 & 78.4 & 91.2 & 83.8 & 153.33 & 4.33 & 10.6 & 10.8 & 74 & 45.4 & 2.73 & 14.2 & 25.4 & 31.8 \\
\hline$\overline{T_{4}}$ & 30.86 & 83 & 89.2 & 81.6 & 153.4 & 4.36 & 11.6 & 10.6 & 74 & 45.6 & 2.73 & 14.6 & 25.73 & 31 \\
\hline$\overline{T_{5}}$ & 30.2 & 84.4 & 89 & 81.4 & 153.93 & 4.4 & 12.6 & 10.2 & 74.06 & 48.4 & 2.93 & 14.4 & 26.2 & 31.6 \\
\hline$T_{6}$ & 30.46 & 85.2 & 89.6 & 81.8 & 154.26 & 4.43 & 10.8 & 10.6 & 74.13 & 49.2 & 3 & 14.6 & 26.46 & 35 \\
\hline$T_{7}$ & 30.53 & 86 & 84.3 & 86.4 & 154.46 & 4.46 & 10.4 & 12.4 & 74.2 & 49.4 & 3 & 14.8 & 26.73 & 33 \\
\hline$T_{8}$ & 31 & 85.6 & 89 & 83.8 & 154.53 & 4.5 & 11.4 & 10.6 & 74.46 & 49.4 & 3.13 & 16 & 26.8 & 32.8 \\
\hline F-test & NS & S & S & S & S & NS & S & NS & NS & S & NS & NS & S & S \\
\hline S.Ed. ( \pm ) & 1.126 & 1.297 & 0.299 & 0.164 & 0.127 & 0.194 & 0.031 & 0.466 & 0.125 & 0.679 & 0.287 & 0.292 & 0.114 & 0.086 \\
\hline $\begin{array}{c}\text { C.D. (at } \\
5 \% \text { ) }\end{array}$ & 2.388 & 2.750 & 0.635 & 0.347 & 0.270 & 0.411 & 0.066 & 0.988 & 0.266 & 0.144 & 0.609 & 0.620 & 0.243 & 0.183 \\
\hline
\end{tabular}


Table.4 Plant yield attributes parameter

\begin{tabular}{|c|c|c|c|c|c|c|}
\hline Treatment & $\begin{array}{c}\text { Siliquae } \\
\text { plant }^{-1}\end{array}$ & $\begin{array}{c}\text { Number of } \\
\text { seed Siliquae }^{-1}\end{array}$ & $\begin{array}{l}\text { Test weight } \\
\text { (g/1000 seed) }\end{array}$ & $\begin{array}{l}\text { Total seed yield } \\
\left(\mathrm{t} . \mathrm{ha}^{-1}\right)\end{array}$ & $\begin{array}{c}\text { Total stover } \\
\text { yield }\left(\mathrm{t} . \mathrm{ha}^{-1}\right)\end{array}$ & $\begin{array}{l}\mathrm{B}: \mathrm{C} \\
\text { ratio }\end{array}$ \\
\hline$T_{0}$ & 73.4 & 45.4 & 2.53 & 12.8 & 25.06 & 31.6 \\
\hline $\mathrm{T}_{1}$ & 73.46 & 49 & 2.66 & 13.6 & 25.33 & 30 \\
\hline$T_{2}$ & 73.66 & 46.8 & 2.26 & 14 & 25.33 & 32.6 \\
\hline$T_{3}$ & 74 & 45.4 & 2.73 & 14.2 & 25.4 & 31.8 \\
\hline$T_{4}$ & 74 & 45.6 & 2.73 & 14.6 & 25.73 & 31 \\
\hline$\overline{T_{5}}$ & 74.06 & 48.4 & 2.93 & 14.4 & 26.2 & 31.6 \\
\hline$T_{6}$ & 74.13 & 49.2 & 3 & 14.6 & 26.46 & 35 \\
\hline$T_{7}$ & 74.2 & 49.4 & 3 & 14.8 & 26.73 & 33 \\
\hline$T_{8}$ & 74.46 & 49.4 & 3.13 & 16 & 26.8 & 32.8 \\
\hline F-test & NS & S & NS & NS & $\mathrm{S}$ & $\mathrm{S}$ \\
\hline S.Ed. $( \pm)$ & 0.125 & 0.679 & 0.287 & 0.292 & 0.114 & 0.086 \\
\hline C.D. (at 5\%) & 0.266 & 0.144 & 0.609 & 0.620 & 0.243 & 0.183 \\
\hline
\end{tabular}

Fig.1 Interaction effect of different doses of sulphur and zinc with NPK on plant height (cm plant $^{-1}$ ) of yellow mustard at 25, 50, 75, 100 and 125 DAS

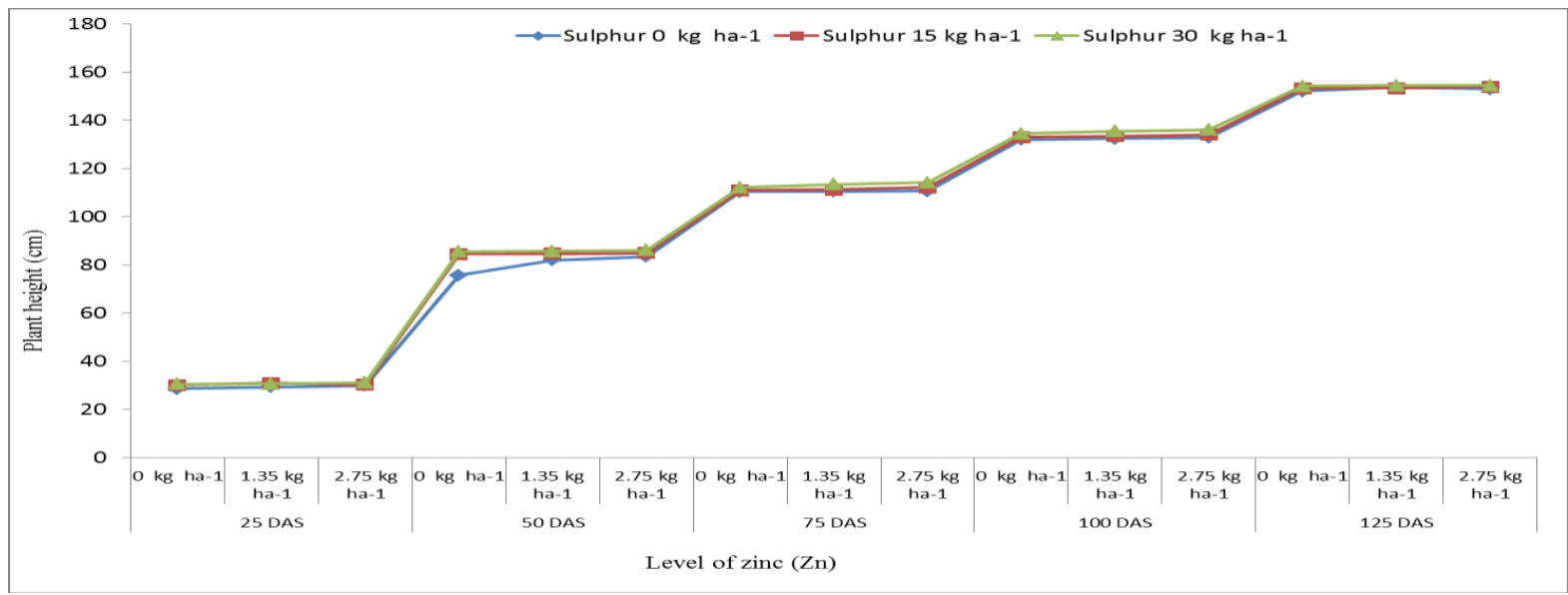

Fig.2 Interaction effect of different doses of sulphur and zinc with NPK on number of leaves plant $^{-1}$ of yellow mustard at 25, 50, 75, 100 and 125 DAS

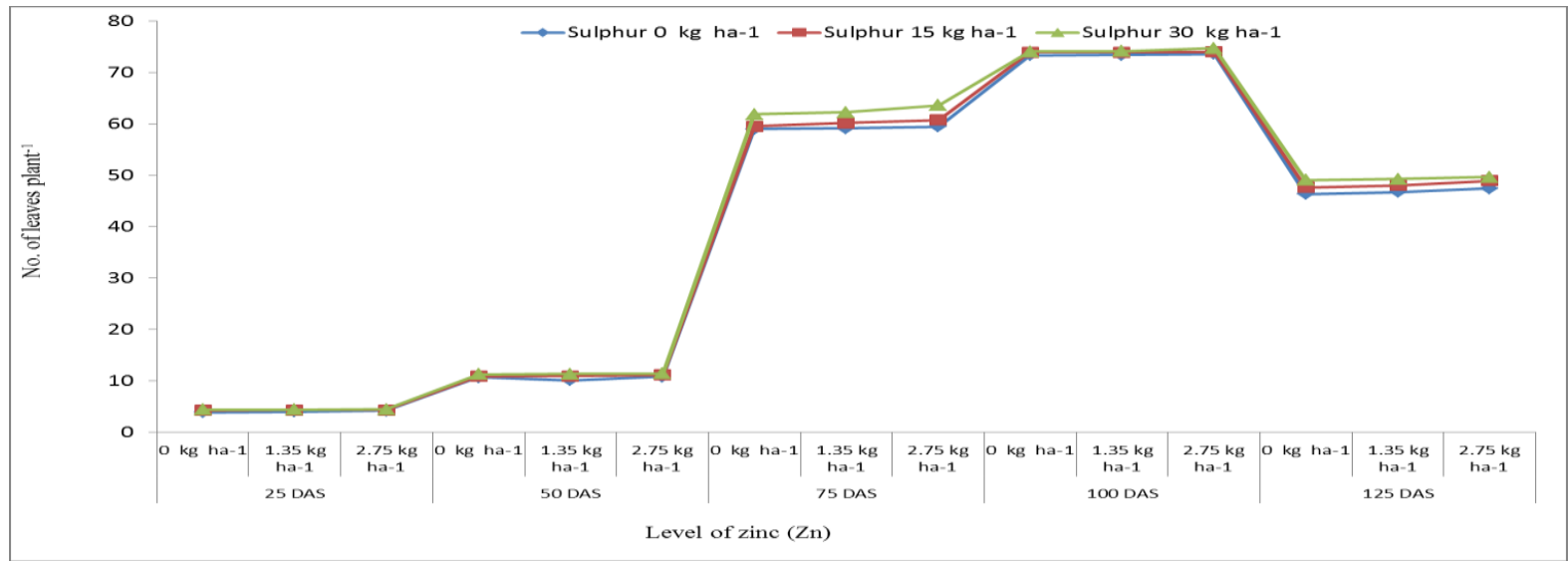


Fig.3 Interaction effect of different doses of sulphur and zinc with NPK on number of branches plant $^{-1}$ of yellow mustard at 50, 75, 100 and 125 DAS

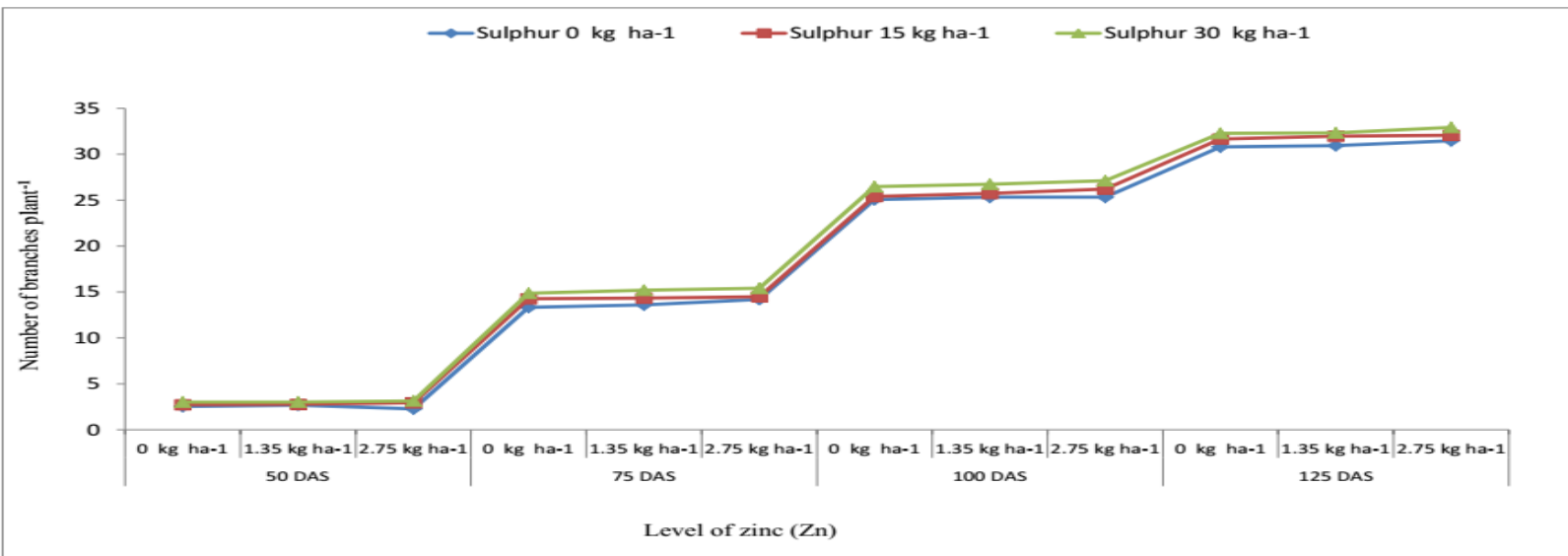

Fig.4 Interaction effect of different doses of sulphur and zinc with NPK on number of siliquae plant $^{-1}$ of yellow mustard

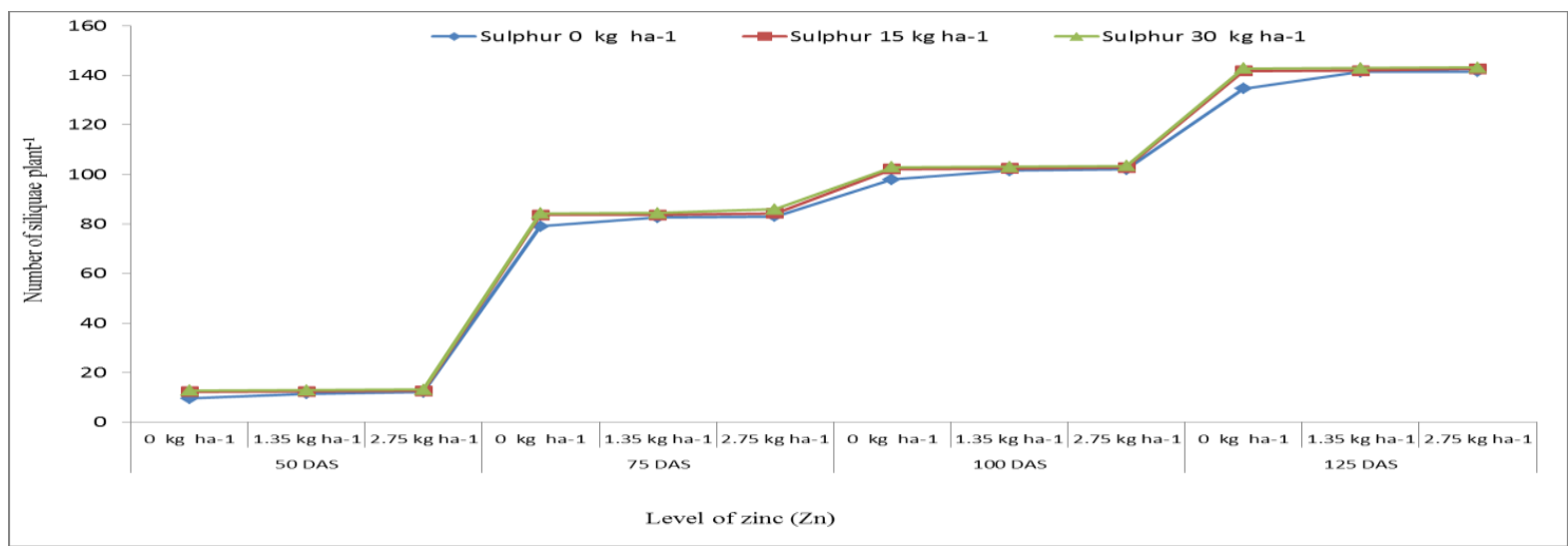

Fig.5 Interaction effect of different doses of sulphur and zinc with NPK on number of seeds siliquae $^{-1}$ of yellow mustard

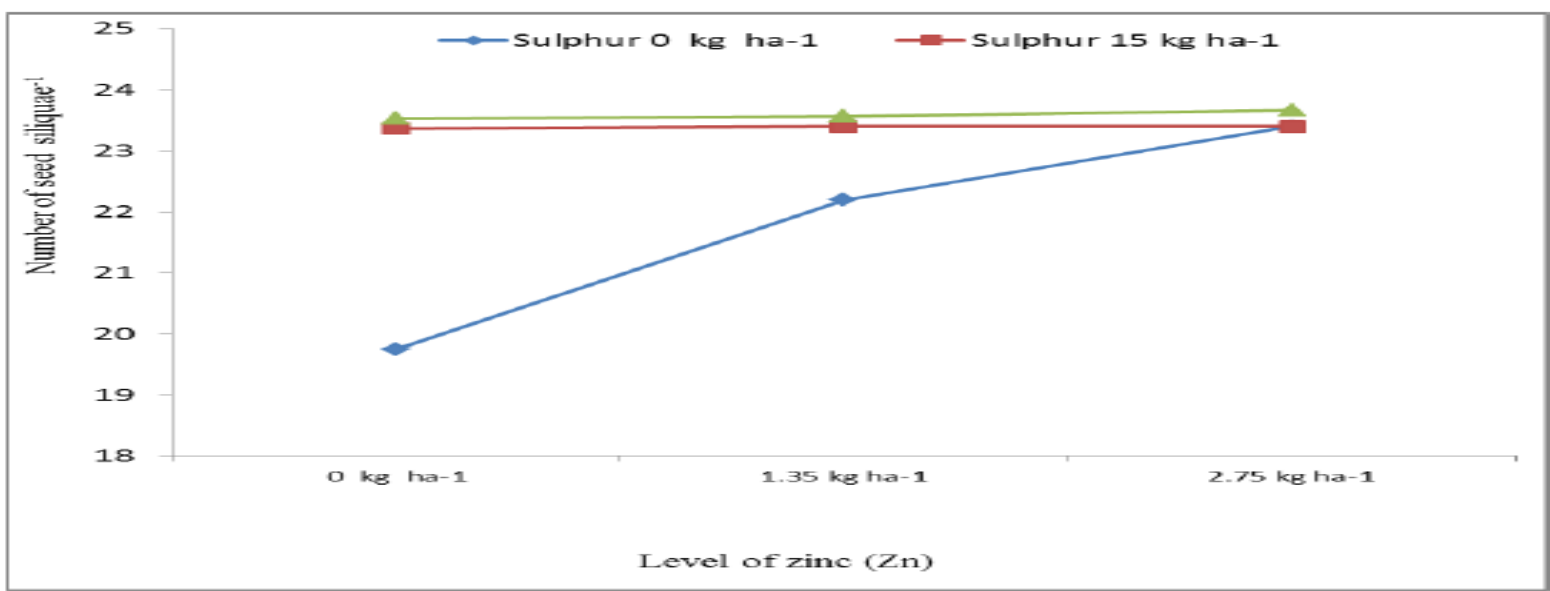


Fig.6 Interaction effect of different doses of sulphur and zinc with NPK on test weight of seeds ( $\mathrm{g} / 1000$ seeds) of yellow mustard

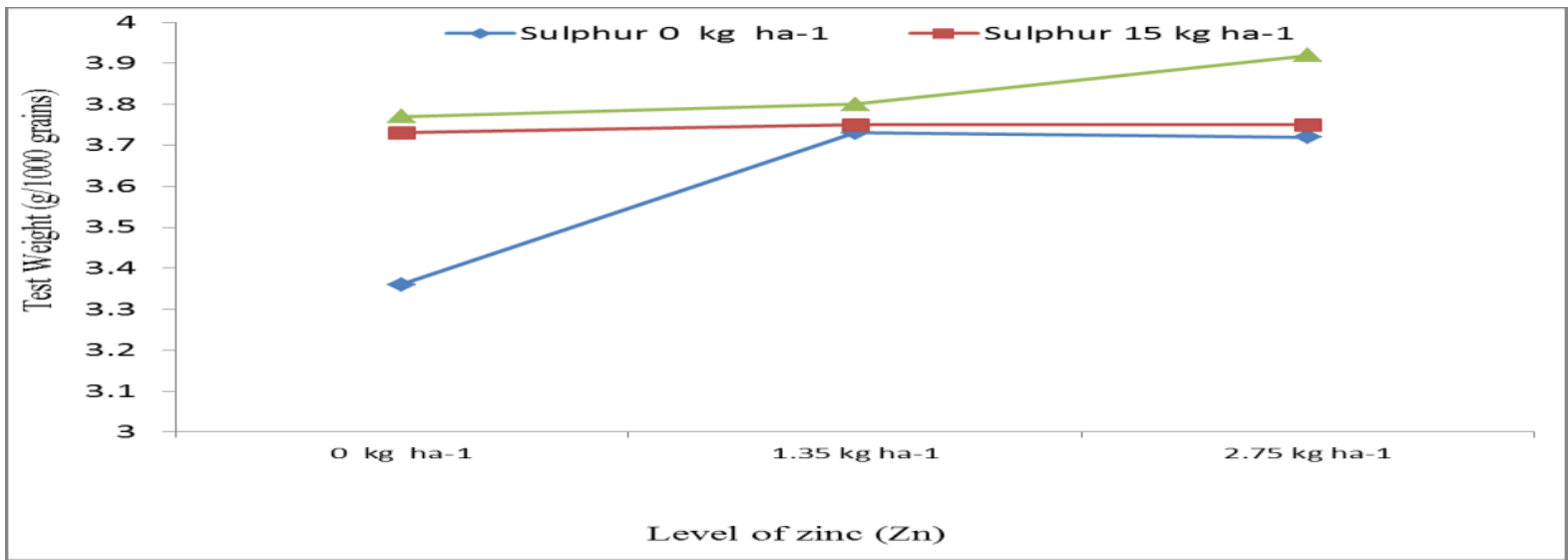

Fig.7 Interaction effect of different doses of sulphur and zinc with NPK on total seed yield $\left(\mathrm{q} \mathrm{ha}{ }^{-1}\right.$ ) of yellow mustard

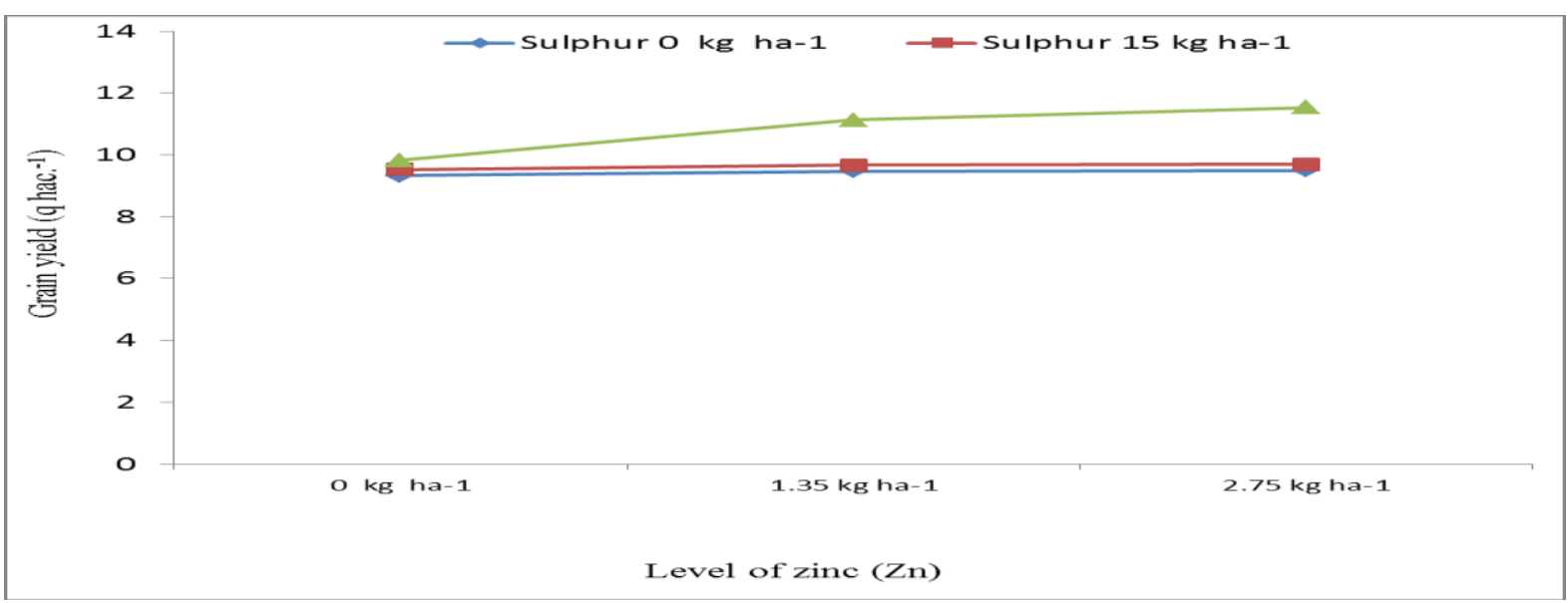

Fig.8 Interaction effect of different doses of sulphur and zinc with NPK on total stover yield $\left(\mathrm{q} \mathrm{ha} \mathrm{h}^{-1}\right.$ ) of yellow mustard

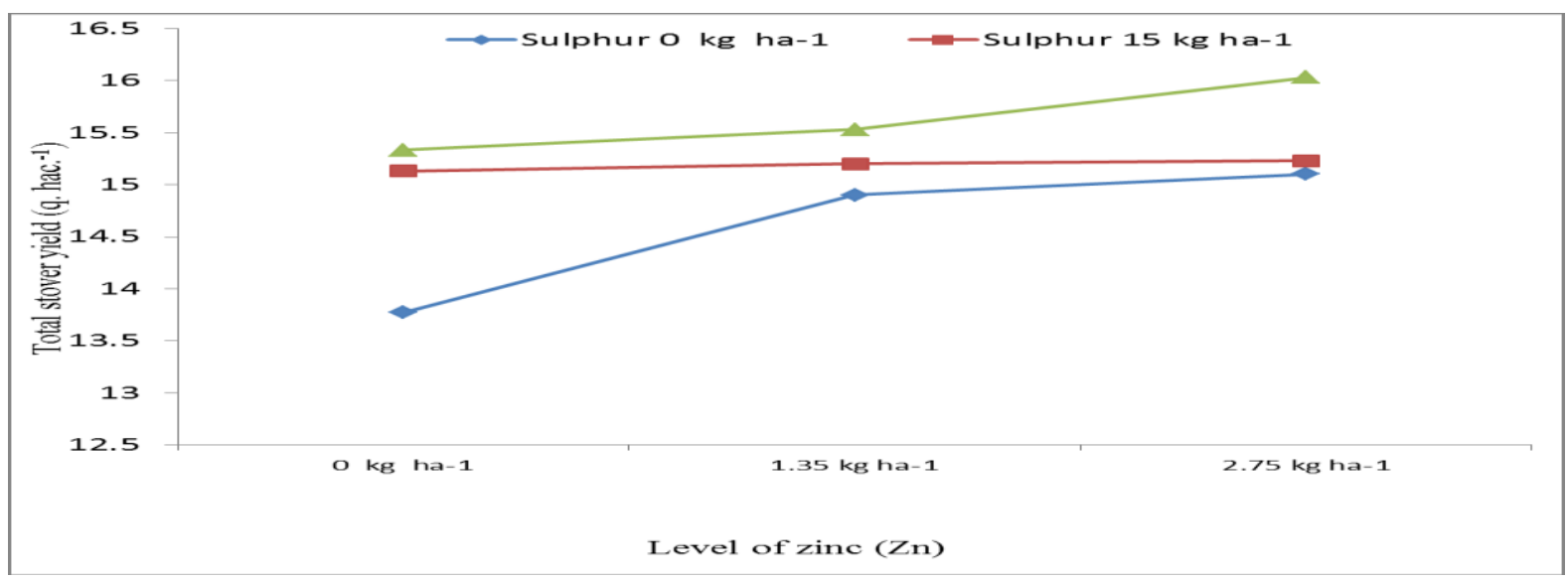


The minimum plant branches was $30.8 \mathrm{~cm}$. was recorded in $\mathrm{T}_{0^{-}} \mathrm{S}_{0} \mathrm{Zn}_{0}$ (@ $0 \mathrm{~kg} \mathrm{ha}^{-1}+0 \mathrm{~kg} \mathrm{ha}^{-1}$ ). Similar results have also been recorded by Baudh and Prasad. (2012).

\section{Number of siliquae plant ${ }^{-1}$}

The number of siliquae plant ${ }^{-1}$ was significant according to table 4 by the application of different treatment of $\mathrm{S}$ and $\mathrm{Zn}$ (sulphur and zinc) interaction. The maximum siliquae plant $^{-1}$ 143.2 was recorded in $\mathrm{T}_{8^{-}}-\mathrm{S}_{2} \mathrm{Zn}_{2}$ (@30 $\mathrm{kg} \mathrm{ha}^{-1}$ $+2.75 \mathrm{~kg} \mathrm{ha}^{-1}$ ) and minimum siliquae plant $^{-1}$ 134.6 was recorded in $\mathrm{T}_{0^{-}} \mathrm{S}_{0} \mathrm{Zn}_{0}\left(@ 0 \mathrm{~kg} \mathrm{ha}^{-1}+\right.$ $\left.0 \mathrm{~kg} \mathrm{ha}{ }^{-1}\right)$. Similar results have also been recorded by Baudh and Prasad. (2012) (Fig. 4).

\section{Number of seeds siliquae ${ }^{-1}$}

The number of seeds siliquae ${ }^{-1}$ was significant according to table 4 by the application of different treatment of $\mathrm{S}$ and $\mathrm{Zn}$ (sulphur and zinc) interaction. Maximum seeds siliquae $^{-1}$ 23.66 was recorded in $\mathrm{T}_{8^{-}} \mathrm{S}_{2} \mathrm{Zn}_{2}$ (@30 kg ha ${ }^{-1}+$ $\left.2.75 \mathrm{~kg} \mathrm{ha}^{-1}\right)$ and minimum seeds siliquae ${ }^{-1}$ 19.26 was recorded in $\mathrm{T}_{0^{-}} \mathrm{S}_{0} \mathrm{Zn}_{0}$ (@ $0 \mathrm{~kg} \mathrm{ha}{ }^{-1}+$ $\left.0 \mathrm{~kg} \mathrm{ha}{ }^{-1}\right)$. Similar results have also been recorded by Dubey et al., (2013) (Fig. 5).

\section{Test weight of seeds (g/1000 seed)}

The test weight of seeds ( $\mathrm{g} / 1000$ seed) was significant according to table 4 by the application of different treatment of $\mathrm{S}$ and $\mathrm{Zn}$ (sulphur and zinc) interaction. The maximum test weight of seeds $3.81 \mathrm{~g}$ was recorded in $\mathrm{T}_{8^{-}}$ $\mathrm{S}_{2} \mathrm{Zn}_{2}$ (@30 kg ha ${ }^{-1}+2.75 \mathrm{~kg} \mathrm{ha}^{-1}$ ) and minimum test weight of seeds was $3.36 \mathrm{~g}$ recorded in $\mathrm{T}_{0^{-}} \mathrm{S}_{0} \mathrm{Zn}_{0}$ (@0 kg ha ${ }^{-1}+0 \mathrm{~kg} \mathrm{ha}^{-1}$ ). Similar results have also been recorded by Dubey et al., (2013) (Fig. 6).

\section{Seed yield $\left(q\right.$ ha $\left.^{-1}\right)$}

The seed yield ( $\mathrm{q} \mathrm{ha}^{-1}$ ) was non-significant according to table 4 by the application of different treatment of $\mathrm{S}$ and $\mathrm{Zn}$ (sulphur and zinc) interaction. The maximum seed yield $11.13 \mathrm{q} \mathrm{ha}^{-1}$ was recorded in $\mathrm{T}_{8^{-}} \mathrm{S}_{2} \mathrm{Zn}_{2}$ (@30 kg $\left.\mathrm{ha}^{-1}+2.75 \mathrm{~kg} \mathrm{ha}^{-1}\right)$ and minimum seed yield $9.33 \mathrm{q} \mathrm{ha}^{-1}$ was recorded in $\mathrm{T}_{0^{-}} \mathrm{S}_{0} \mathrm{Zn}_{0}$ (@ $0 \mathrm{~kg}$ $\left.\mathrm{ha}^{-1}+0 \mathrm{~kg} \mathrm{ha}^{-1}\right)$. Similar results have also been recorded by Dubey et al., (2013) (Fig. 7).

\section{Stover yield (q ha $\left.{ }^{-1}\right)$}

The stover yield $\left(\mathrm{q} \mathrm{ha}^{-1}\right)$ was non-significant according to table 4 by the application of different treatment of $\mathrm{S}$ and $\mathrm{Zn}$ (sulphur and zinc) interaction. Stover yield was found maximum stover yield $15.70 \mathrm{q} \mathrm{ha}^{-1}$ was recorded in $\mathrm{T}_{8^{-}} \mathrm{S}_{2} \mathrm{Zn}_{2}$ (@30 $\mathrm{kg} \mathrm{ha}^{-1}+2.75 \mathrm{ha}^{-1}$ ) and minimum stover yield $13.77 \mathrm{q} \mathrm{ha}^{-1}$ was recorded in $\mathrm{T}_{0^{-}} \mathrm{S}_{0} \mathrm{Zn}_{0}$ (@0 kg ha ${ }^{-1}+0 \mathrm{ha}^{-1}$ ). Similar results have also been recorded by Dubey et al., (2013) (Fig. 8).

\section{B: C ratio}

The treatment combination of $\mathrm{S}$ and $\mathrm{Zn}$ (sulphur and zinc) $\mathrm{T}_{8} \mathrm{~S}_{2} \mathrm{Zn}_{2}$ (@30 kg ha ${ }^{-1}+2.75 \mathrm{~kg} \mathrm{ha}^{-1}$ ) was found the best combination. Highest net return ₹ $15540.12 \mathrm{ha}^{-1}$ and $\mathrm{B}$ : C 1.57 was also recorded in this treatment. It is concluded that the best treatment was $\mathrm{T}_{8}-\mathrm{S}_{2}+\mathrm{Zn}_{2}$ [@30 sulphur kg ha ${ }^{-1}+2.75$ zinc kg ha $^{-1}$ ] that showed the highest yield regarding, it gave the best results with respect to plant height $154.53 \mathrm{~cm}$, number of leaves 74.46 , number of branches 32.6, number of siliquae per plant 143.2, number of seed per siliquae 23.66, test weight of 1000 seed $3.81 \mathrm{gm}$, it gives highest yield $11.53 \mathrm{q} \mathrm{ha}^{-1}$ recorded.

\section{Acknowledgement}

Authors are sincerely thankful to Dr. Narendra Swaroop, Associate Prof., Department of soil Science and Agricultural Chemistry, Dileshwar Prasad research scholar Department of soil Science and Agricultural Chemistry, Sam Higginbottom University of Agriculture, Technology and Sciences, Allahabad. Dineshwar Singh Kanwar Department of Plant Physiology, Indira Gandhi Krishi Vishwavidyalata, Raipur and Prahlad Singh, Department of Plant Pathology, Indira Gandhi krishi vishwavidyalata, Raipur. 


\section{References}

Anonymous, (1971) Munsell Soil Colour chart. Munsellcolour Company Inc. $2441 \mathrm{~N}$, Calvert Street, Baltimore Maryland 21212, USA.

Bardsley, C.E. and Lancaster J. D. (1960). Determination of reserve sulphur and soluble sulphates in soil. Soil Sci. Soc. Amer. Proc. 24 pp.265- 268

Baudha, A.K. and Prasad, G. (2012). Interaction effect of different dose of sulphur and zinc with nitrogen, phosphorus and organic manure on growth and productivity of mustard (Brassica compestris). Indian J.Sci.Res. 3(1): pp.141-144.

Bouyoucos, G.J. (1927). The hydrometer as a new method for the mechanical analysis of soil. Soil Sci. 23. pp. 343-353

Dubey, S. K., Tripathi, S. K. and Singh, B. (2013). Effect of Sulphur and Zinc Levels on Growth, Yield and Quality of Mustard [Brassica juncea (L.) Czern \& Coss.] Research \& Reviews: A Journal of Crop Science and Technology, Volume (2), Issue 1.

Holmes, R. S. (1945) Determination of total copper, zinc, cobalt, lead in soil and Soil solution, Soil Sci. 59. pp. 77-84.

Jackson, M.L. (1958) Soil Chemical Analysis, Prentice Hall of India Private Limited, New Delhi.

Muthuval P., C. Udaysoorian, R. Natesan, P.P. Ramaswami (1992). Introduction to Soil analysis, Tamil Nadu Agricultural University, Coimbatore-641002

Olsen S.R., Cole, C.V., Watnahe, F.S. and Dean L.A. (1954). Estimation of available phosphorous in soil by extraction with sodium bicarbonate U.S. Dept. Agr. Cric. 939.
Piri, I. (2012). Study of yield and yield components of black mustard (Brassica nigra) in condition of sulphur application and water stress. Annals of Biological Research, 3 (5):2074-2077.

Shaw E. and Dean L. A. (1952). The use of dithizone as an extractant to estimation the nutrient status of soil. Soil Sci. 73. pp. 341344.

Subbiah B. V. and Asija C. L. (1956) A rapid procedure for the estimation of available nitrogen in soil, Current Sci. 25. pp. 259260.

Thakkar, D.P, Smile and M. (2005) Reclamation of Zinc. Journal of Indian society of Soil Science. 2005, 36:2, pp.311-312.

Toth, S. J. and Prince A. L. (1949). Estimation of cation exchange capacity and exchangeable $\mathrm{Ca} \mathrm{K}$ and $\mathrm{Na}$ Content of Soil by Flame photometer technique. Soil Sci. 67. pp. 439445.

Upadhyay, Y., Swaroop, N., Sahu, Y. K., Dhruw, S. S. and Verma, P. D. (2016). Interaction effects of different doses of sulphur and zinc with NPK on physico -chemical properties of soil in yellow mustard (Brassica compestris L.) Cv. Krishna Super Goldi. International Journal of Agricultural Science and Research (IJASR), vol. (6).

Walkley, A. (1947). Critical examinationof rapid method for determining organic carbon in soil, effect of variation in digestion condition and of inorganic soil constitutes. Soil Sci. 632-251.

Wilcox L.V. (1950) Electrical conductivity, Amer. water works assoc. J. 42. pp. 775-776

Yadav, R., Singh, P. K., Singh, R. K., Tiwari, P. and Singh, S. N. (2017). Impact of Sulphur Nutrition on Promising Mustard Cultivars in Eastern Uttar Pradesh. Int. J. Pure App. Biosci. (5) Pp. 389-394.

\section{How to cite this article:}

Dogendra Kumar Sahu, Narendra Swaroop, Dileshwar Prasad, Dineshwar Singh Kanwar and Prahlad Singh. 2018. Effect of Different Doses of Sulphur and Zinc with NPK on Different Growth Parameters and Yield Attribute of Yellow Mustard (Brassica compestris L.) cv. Sunanda. Int.J.Curr.Microbiol.App.Sci. 7(03): 1014-1022.

doi: https://doi.org/10.20546/ijcmas.2018.703.121 